\title{
Toxicity of Pyrifluquinazon against Greenhouse Whitefly on Tomato Produced in Greenhouses
}

\author{
Paul McLeod1*, Tahir Rashid² \\ ${ }^{1}$ Department of Entomology, University of Arkansas, Fayetteville, USA \\ ${ }^{2}$ Extension/Research Demonstration Farm, Alcorn State University, Mound Bayou, USA \\ Email: *pjmcleod@uark.edu
}

Received 4 April 2014; revised 14 May 2014; accepted 18 June 2014

Copyright (C) 2014 by authors and Scientific Research Publishing Inc.

This work is licensed under the Creative Commons Attribution International License (CC BY).

http://creativecommons.org/licenses/by/4.0/

(c) (i) Open Access

\section{Abstract}

The greenhouse whitefly, Trialeurodes vaporariorum (Westwood), is a major pest of tomato, Solanum lycopersicum L. Management in both the field and greenhouse is often based on foliar applications of insecticides. A lack of control along with resistance development requires development of alternatives to currently available insecticides. Pyrifluquinazon is a recently developed insecticide by Nichino/Nihon Nohyaku Co., Japan and is marketed in the US by Nichino America. The insecticide inhibits feeding by aphids, thrips, mealybugs and scale insects resulting in death. Because limited information exists on pyrifluquinazon effectiveness against whiteflies, tests were initiated to establish its toxicity against the greenhouse whitefly on greenhouse produced tomato. Data reported herein indicate that pyrifluquinazon was highly effective against adult greenhouse whiteflies. When adults were transferred to tomato shortly after the application had dried, mortality counts taken after $48 \mathrm{~h}$ produced $\mathrm{LC}_{50}$ and $\mathrm{LC}_{95}$ values of 0.2469 and $2.4826 \mu \mathrm{g} \cdot \mathrm{g}^{-1}$, respectively. Although few adults were observed on tomato foliage $24 \mathrm{~h}$ post-exposure, little mortality was observed until the $48 \mathrm{~h}$ observation. When adult whiteflies were placed on tomato $3 \mathrm{~d}$ after pyrifluquinazon application, the $\mathrm{LC}_{50}$ value was $0.3343 \mu \mathrm{g} \cdot \mathrm{g}^{-1}$ which did not significantly differ from the $0 \mathrm{~h} \mathrm{LC} \mathrm{L}_{50}$ value. A significant increase in $\mathrm{LC}_{50}$ value was observed when adults were placed on tomato $5 \mathrm{~d}$ after pyrifluquinazon application. In a greenhouse efficacy trial, both the recommended pyrifluquinazon rate (46.8 $\mathrm{g}$ active ingredient $\left.[\mathrm{AI}] \mathrm{ha}^{-1}\right)$ and a reduced rate $\left(11.7 \mathrm{~g} \cdot \mathrm{AI} \cdot \mathrm{ha}^{-1}\right)$ significantly reduced numbers of whitefly adults when compared to the non-treated control for 10 days. The $46.8 \mathrm{~g} \cdot \mathrm{AI} \cdot \mathrm{ha}^{-1}$ rate was as effective as the insecticide standard, imidacloprid. Pyrifluquinazon applied to tomato foliage in the greenhouse offers a useful alternative to currently available insecticides for control of greenhouse whitefly. Further, its unique mode of action may represent a new tool in management of insecticide resistance.

${ }^{*}$ Corresponding author. 


\section{Keywords}

\section{Greenhouse Whitefly, Trialeurodes vaporariorum, Pyrifluquinazon, Insecticide}

\section{Introduction}

The greenhouse whitefly, Trialeurodes vaporariorum (Westwood) has become a major pest of tomato, Solanum lycopersicum L., produced in greenhouses. The whitefly extracts sap from the plant thereby reducing plant vigor, produces honeydew and can transmit viral diseases [1] [2]. Heavily infested plants are distorted; leaves are discolored and fruit production is reduced. Whitefly management is generally based on application of foliar insecticide when pest levels are low. Once population levels are high, management is very difficult [3] [4]. The neonicotinoid group of insecticides, is generally among the most effective insecticides against whiteflies, however, producers are concerned with development of resistance [5]. Because of resistance concerns, the industry is continually interested in development of new alternative insecticides against whiteflies. Pyrifluquinazon is a new insecticide developed by Nichino/Nihon Nohyaku Co., Japan and is marketed in the US by Nichino America. Pyrifluquinazon affects the behavior of aphids, thrips, mealybugs and scale insects. Upon exposure, the insect stops feeding and death occurs by starvation [6]. Schuster et al. [7] and Palumbo [8] reported that pyrifluquinazon was effective against whiteflies in field trials. No information on the efficacy of pyrifluquinazon against the greenhouse whitefly on greenhouse produced tomato has been reported. The objective of the study reported herein was to establish the effectiveness of pyrifluquinazon against the greenhouse whitefly on greenhouse produced tomato.

\section{Materials and Methods}

\subsection{Insect Source}

The whiteflies used in the study were collected from "Bradley" tomato grown in a greenhouse at the University of Arkansas Main Experimental Station, Fayetteville. Seed were obtained from the Green Seed Co., Inc., Springfield, MO. Beginning in fall of 2012, tomatoes were maintained in $19 \mathrm{~L}$ plastic pots containing potting soil (Scott's Moisture Advantage, Scott's Company, Marysville, OH). Plants were produced following industry recommendations including fertilization and irrigation practices. No insecticides were applied. An infestation of greenhouse whitefly has been common in the greenhouse during the past several years and again developed on the tomato during the fall and was present throughout the winter and spring. At time of whitefly collection, plants were greater than $1 \mathrm{~m}$ in height and fruiting. Whitefly adults were collected as follows. Individual insects were vacuumed from the tomato leaf surface with the aid of a hand held "flashlight" aspirator (Hausherr's Machine Works, Toms River, NJ). The collection container consisted of a 7-dram plastic vial with the bottom removed and covered with screen. Once a sufficient number of whiteflies were aspirated into the tube, the aspirator neck was removed and a cap was placed over the opening. This was completed with the aspirator running to prevent escape. Capped vials were held in a cooled ice chest until the required number were collected.

\subsection{Test Plants}

Tomato cv "Bradley" plants were produced in $3.8 \mathrm{~L}$ plastic pots containing potting soil (Scott's Moisture Advantage, Scott’s Company, Marysville, $\mathrm{OH}$ ) from seed obtained from the Green Seed Co., Inc., Springfield, MO. Plants were produced from Sept 2012 through May 2013 in the vegetable insect greenhouse located at the University of Arkansas Main Experimental Station, Fayetteville, Arkansas. Temperature was maintained between $25^{\circ} \mathrm{C}$ and $29^{\circ} \mathrm{C}$ with natural light. Once plants developed six true leaves, two slotted disks of blue sill foam (Dow Chemical Co., Midland, MI) were placed on the soil surface. These formed a tight closure around the plant stem thereby preventing whiteflies from moving to the soil and to facilitate counting. Plants were then individually caged with a $3.8 \mathrm{~L}$ paint strainer (Trimaco, LLC, Durham, NC). The strainers were made of tightly woven nylon and measured $25 * 30 \mathrm{~cm}$. The open end contained an elastic band. Any whiteflies that were detected on the plants were removed before caging. 


\subsection{Dosage-Mortality Response}

The test insecticide was NNI0101, a formulation containing 20\% pyrifluquinazon, supplied by Nichino America. The insecticide was mixed with $500 \mathrm{~mL}$ water containing $0.025 \%$ non-ionic surfactant. The resulting concentration was $30 \mu \mathrm{g} \cdot \mathrm{g}^{-1}$ pyrifluquinazon:water. This was further serially diluted to $3,0.3$ and $0.03 \mu \mathrm{g} \cdot \mathrm{g}^{-1}$. Each pyrifluquinazon mixture along with a water check was placed in a hand operated sprayer (Gilmour Manufacturing Co., Somerset, PA) that was calibrated to deliver $388 \mathrm{~L} / \mathrm{ha}$. For each concentration, four caged tomato plants with about eight true leaves were selected and cages were removed. Each mixture was applied to the upper and lower leaf surface of tomato foliage and allowed to dry before plants were again caged. A single capped vial containing 10 adult whiteflies was placed on the foam disk surface by carefully pulling the paint strainer cage from the pot. After the cage was again closed around the pot, the vial was lifted, uncapped and left on the soil surface for the whiteflies to emerge. Each test was repeated five times. A total of 200 whiteflies was tested for each concentration. Tests were initiated immediately after the spray had dried (0 days after treatment [DAT]) and at three and five DAT. Caged plants were held on a laboratory bench with natural sunlight and temperature of $23^{\circ} \mathrm{C}$. For each test, the numbers of live and dead whiteflies were counted 24 and $48 \mathrm{~h}$ post infestation. Lack of movement after prodding was used as the criterion for judging death. Data were corrected for control mortality and analyzed with Proc Probit (SAS 9.1, SAS Institute, Cary, NC).

\subsection{Greenhouse Efficacy Trial}

Plants used in the efficacy study were as described above and grown in $3.8 \mathrm{~L}$ plastic pots in the vegetable greenhouse. Once plants developed six true leaves they were removed from the greenhouse for insecticide application. Sprays were applied through a single nozzle with a $\mathrm{CO}_{2}$ propelled backpack sprayer calibrated to deliver 104.7 L per ha. Both the leaf top and bottom were sprayed. On each test date 15 plants were used for each treatment (pyrifluquinazon $46.8 \mathrm{~g} \cdot \mathrm{AI} \cdot \mathrm{ha}^{-1}$; pyrifluquinazon $11.7 \mathrm{~g} \cdot \mathrm{AI} \cdot \mathrm{ha}^{-1}$; Provado 1.6 at $53.3 \mathrm{~g} \cdot \mathrm{AI} \cdot \mathrm{ha}^{-1}$; and a water treated control). Each treatment included $0.025 \%$ non-ionic surfactant. Immediately after sprays had dried, plants were returned to the greenhouse. Insecticide effectiveness was assessed as follows. Two plants from each treatment were removed to the laboratory at 1, 2, 3, 5, 7 and 10 DAT. In the laboratory, plants were caged with a $3.8 \mathrm{~L}$ paint strainer and a vial containing 25 adult greenhouse whiteflies was opened within the cage as described above. Live and dead whiteflies were counted after $48 \mathrm{~h}$. Experimental design was RCB and was repeated four times. Data were analyzed with GLM and when F values were significant means were separated with LSD (SAS 9.1, SAS Institute, Cary, NC).

\section{Results and Discussion}

\subsection{Dosage-Mortality Response}

Pyrifluquinazon was highly effective against greenhouse whitefly adults on tomato. When whiteflies were released immediately after the application had dried (0 DAT), subsequent observations taken $24 \mathrm{~h}$ after the release found few whiteflies on the foliage of any treated plant. Most whiteflies were on the foam disk under the plant. When prodded, movement was generally detected but was often uncoordinated. By the $48 \mathrm{~h}$ observation following infestation, whitefly mortality was evident. At the highest tested rate of $30 \mu \mathrm{g} \cdot \mathrm{g}^{-1} 100 \%$ of the adult whiteflies were dead at the $48 \mathrm{~h}$ observation. The $\mathrm{LC}_{50}$ value generated for foliage infested with whiteflies immediately after application was $0.25 \mu \mathrm{g} \cdot \mathrm{g}^{-1}$ with fiducial limits of 0.20 to 0.30 (Table 1). The $\mathrm{LC}_{95}$ value was $2.48 \mu \mathrm{g} \cdot \mathrm{g}^{-1}$ and the $X^{2}$ value was 250.67 which was significant and indicated that increase in dose resulted in an increase in mortality. Little change in toxicity was evident when foliage was assayed 3 DAT. Again, mortality was 100\% for the highest tested rate of $30 \mu \mathrm{g} \cdot \mathrm{g}^{-1}$. Based on overlap of the $95 \%$ fiducial limits, the 0 and 3 DAT LC ${ }_{50}$ values did not significantly differ (Table 1 ). The $\mathrm{LC}_{95}$ value was $5.81 \mu \mathrm{g} \cdot \mathrm{g}^{-1}$ and was significantly greater than that for 0 DAT. A decline in toxicity was observed for foliage tested 5 DAT. Although whitefly mortality on foliage receiving the high dose of $30 \mu \mathrm{g} \cdot \mathrm{g}^{-1}$ was $85 \%$, a significant increase in the $\mathrm{LC}_{50}$ value was detected, i.e., 2.94 $\mu \mathrm{g} \cdot \mathrm{g}^{-1}$ (Table 1). The $\mathrm{LC}_{95}$ value was $141.42 \mu \mathrm{g} \cdot \mathrm{g}^{-1}, 57$ times greater than that for 0 DAT.

\subsection{Greenhouse Efficacy Trial}

Each of the three foliar applications effectively reduced the number of adult greenhouse whiteflies on tomato (Table 2). At 1 DAT following the release of 25 adults the mean number of adults per plant ranged from 0 for 
Table 1. Dosage-mortality response parameters for greenhouse whitefly adults exposed to pyrifluquinazon on tomato.

\begin{tabular}{cccccc}
\hline $\mathrm{DAT}^{\mathrm{a}}$ & $\mathrm{n}$ & Slope $\pm \mathrm{SE}$ & $X^{2}$ & $\mathrm{LC}_{50}\left(\mu \mathrm{g} \cdot \mathrm{g}^{-1}\right)(95 \% \mathrm{FL})^{\mathrm{b}}$ & $\mathrm{LC}_{95}\left(\mu \mathrm{g} \cdot \mathrm{g}^{-1}\right)(95 \% \mathrm{FL})^{\mathrm{a}}$ \\
\hline 0 & 800 & $1.64 \pm 0.10$ & 250.67 & $0.25(0.20-0.30)$ & $2.48(1.83-3.62)$ \\
3 & 800 & $1.33 \pm 0.08$ & 297.92 & $0.33(0.27-0.41)$ & $5.81(4.09-8.89)$ \\
5 & 800 & $0.98 \pm 0.06$ & 269.35 & $2.94(2.29-3.83)$ & $141.42(84.55-267.65)$ \\
\hline
\end{tabular}

${ }^{\mathrm{a}}$ Days after treatment. ${ }^{\mathrm{b}} 95 \%$ lower and upper fiducial limits.

Table 2. Mean number of surviving adult greenhouse whiteflies per tomato plant following insecticide application in a greenhouse ${ }^{\mathrm{a}}$.

\begin{tabular}{|c|c|c|c|c|c|c|c|}
\hline \multirow{2}{*}{ Treatment } & \multirow{2}{*}{ Rate $\left(\mathrm{g} \cdot \mathrm{AI} \cdot \mathrm{ha}^{-1}\right)$} & \multicolumn{6}{|c|}{ Days after treatment } \\
\hline & & 1 & 2 & 3 & 5 & 7 & 10 \\
\hline Pyrifluquinazon 20 SC & 11.7 & $0.5^{\mathrm{a}}$ & $0.5^{\mathrm{a}}$ & $0.5^{\mathrm{a}}$ & $0.7^{\mathrm{a}}$ & $2.2^{\mathrm{a}}$ & $6.3^{\mathrm{a}}$ \\
\hline Pyrifluquinazon 20 SC & 46.8 & $0.0^{\mathrm{a}}$ & $0.0^{\mathrm{a}}$ & $0.0^{\mathrm{a}}$ & $0.0^{\mathrm{a}}$ & $0.0^{\mathrm{b}}$ & $0.0^{\mathrm{b}}$ \\
\hline Provado 1.6 F & 53.3 & $0.2^{\mathrm{a}}$ & $0.0^{\mathrm{a}}$ & $0.3^{\mathrm{a}}$ & $0.2^{\mathrm{a}}$ & $0.5^{\mathrm{b}}$ & $0.2^{\mathrm{b}}$ \\
\hline Control & - & $24.8^{\mathrm{b}}$ & $24.5^{\mathrm{b}}$ & $23.5^{\mathrm{b}}$ & $24.5^{\mathrm{b}}$ & $24.7^{\mathrm{C}}$ & $23.2^{\mathrm{c}}$ \\
\hline
\end{tabular}

${ }^{\mathrm{a}}$ Plants were caged with a $3.8 \mathrm{~L}$ paint strainer and 25 whiteflies were released on each plant. Survival was determined $48 \mathrm{~h}$ after release. ${ }^{\mathrm{b}} \mathrm{Within}$ column means followed by the same letter do not significantly differ. P = 0.05; LSD.

the high rate of pyrifluquinazon to 24.8 for water treated plants. No significant differences were detected for surviving adults among the three insecticide treatments. Similar results were observed for the 2, 3, and 5 DAT sample dates with no significant differences detected among the three insecticides. Whitefly survival on water treated plants was high throughout the $10 \mathrm{~d}$ study and ranged from 24.8 per plant for the 1 DAT sample to 23.2 per plant for the 10 DAT sample. At 7 DAT significantly more whiteflies survived on plants treated with the lower rate of pyrifluquinazon than on plants receiving the higher pyrifluquinazon rate or Provado (Table 2). However, survival on plants treated with the lower pyrifluquinazon rate was still significantly reduced when compared to water treated tomato plants. A similar trend was observed for the 10 DAT sample period with no live whiteflies found on tomato plants receiving the higher pyridluquinazon rate.

\section{Conclusion}

The greenhouse whitefly is a major pest of greenhouse produced tomato and has high potential for development of resistance to insecticides. Because of resistance concerns, alternatives to currently used insecticides are needed. Pyrifluquinazon is a newly developed insecticide that reduces feeding of aphids, thrips, mealybugs and scale insects. Results reported herein indicate that pyrifluquinazon is also effective against the greenhouse whitefly on tomato. In laboratory bioasays adult whiteflies were observed to leave treated tomato foliage within 24 $\mathrm{h}$ after release. Although movement was still seen $24 \mathrm{~h}$ after exposure, it was generally uncoordinated. By $48 \mathrm{~h}$ after exposure all whiteflies exposed to the highest tested pyrifluquinazon dose were dead. Toxicity persisted for several days on tomato foliage and mortality resulting from the high dose was still 100\% 5 DAT. Greenhouse efficacy tests indicated that the recommended rate of pyrifluquinazon, i.e., $46.8 \mathrm{~g} \cdot \mathrm{AI} \cdot \mathrm{ha}^{-1}$, was as effective as the insecticide standard, Provado. Whitefly mortality was similar for both applications throughout the 10 day study. A reduced rate of $11.7 \mathrm{~g} \cdot \mathrm{AI} \cdot \mathrm{ha}^{-1}$ pyrifluquinazon also was as effective against adult whiteflies as the standard for $5 \mathrm{~d}$ and high mortality continued through the $10 \mathrm{~d}$ study. Data from this study indicate that pyrifluquinazon is an excellent candidate for management of adult greenhouse whitefly on tomato produced in greenhouse. Its unique mode of action also may offer a new tool in resistance management.

\section{References}

[1] Bi, J.L., Toscano, N.C. and Ballmer, G.R. (2002) Seasonal Population Dynamics of the Greenhouse Whitefly Tialeurodes vaporariorum (Homoptera: Aleyrodidae) on Strawberries in Southern California. Journal of Economic Entomology, 95, 1179-1184. http://dx.doi.org/10.1603/0022-0493-95.6.1179 
[2] Duffus, J.E., Liu, H.Y. and Wisler, G.C. (1996) Tomato Infectious Chlorosis Virus-A New Clostero-Like Virus Transmitted by Trialeurodes vaporariorum. European Journal of Plant Pathology, 102, 219-226. http://dx.doi.org/10.1007/BF01877960

[3] McLeod, P. (2006) Identification, Biology and Management of Insects Attacking Vegetables in Arkansas. Sirena Press, Santa Cruz, Bolivia, 244 p.

[4] Sorensen, K.A. and Baker, J.R. (1994) Insect and Related Pests of Vegetables. Bulletin AG-295, North Carolina Cooperative Extension Service, Raleigh.

[5] Omer, A.D., Leigh, T.F. and Granett, J. (1992) Insecticide Resistance in Field Populations of Greenhouse Whitefly (Homoptera: Aleyrodidae) in the San Joaquin Valley Cotton System. Journal of Economic Entomology, 85, 21-27.

[6] Chem Service, Inc., West Chester. http://www.chemservice.com/

[7] Schuster, D.J., Kalb, S. and Shurtleff, A. (2009) Silverleaf Whitefly and TYLCV Control on Fresh Market Tomatoes with Soil and Folliar Insecticide Applications, Spring 2008. Arthropod Management Tests, 34, E80.

[8] Palumbo, J.C. (2011) Sweetpotato Whitefly Control with Soil and Folira Insecticides on Broccoli, 2009. Arthropod Management Tests, 36, E13. http://www.chemservice.com/customer/account/ http://www.chemservice.com/checkout/cart/ 
Scientific Research Publishing (SCIRP) is one of the largest Open Access journal publishers. It is currently publishing more than 200 open access, online, peer-reviewed journals covering a wide range of academic disciplines. SCIRP serves the worldwide academic communities and contributes to the progress and application of science with its publication.

Other selected journals from SCIRP are listed as below. Submit your manuscript to us via either submit@scirp.org or Online Submission Portal.
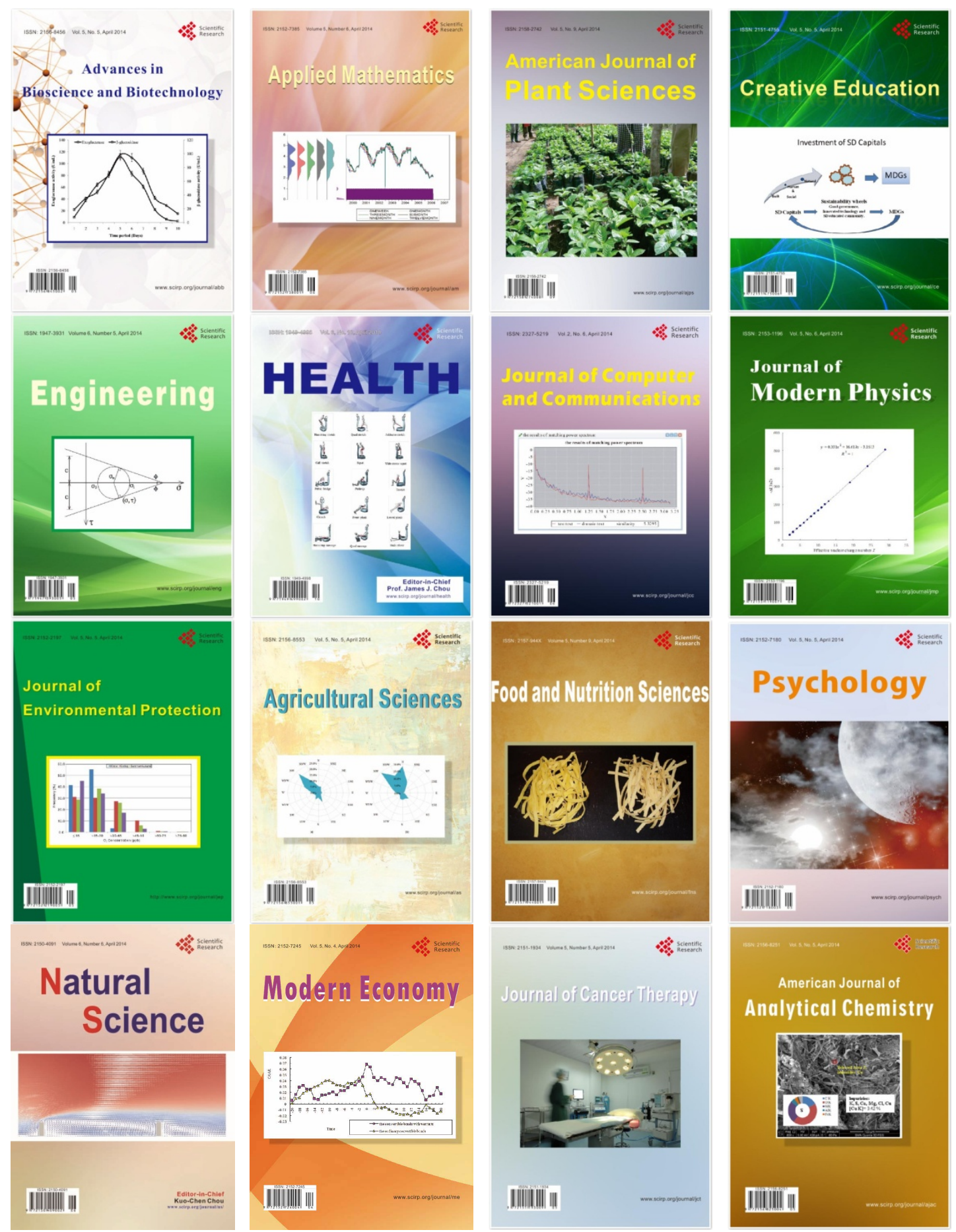